\title{
Short Communication: Floral diversity of honey bee-collected pollen (Apis cerana) colonies in the Ir. H. Djuanda Forest Park, West Java, Indonesia
}

\author{
SYAYIDAH NURIYAH ${ }^{1}$, TEGUH HUSODO ${ }^{1,2,3, \bullet}$, WAWAN HERMAWAN ${ }^{2}$, ARIEF ANSHORY YUSUF ${ }^{1}$, \\ HIKMAT KASMARA ${ }^{2}$, JOKO KUSMORO ${ }^{2}$, INDRI WULANDARI ${ }^{1,2,3}$, SYA SYA SHANIDA ${ }^{3}$ \\ ${ }^{1}$ Doctoral Program in Environmental Science, School of Graduates, Universitas Padjadjaran. Jl. Dipati Ukur No. 35, Bandung 40132, \\ West Java, Indonesia \\ ${ }^{2}$ Department of Biology, Faculty of Mathematics and Natural Sciences, Universitas Padjadjaran. Jl. Raya Bandung-Sumedang Km 21, Jatinangor, \\ Sumedang 45363, West Java, Indonesia. Tel.: +62-22-84288888, `email: teguhhusodo2@gmail.com \\ ${ }^{3}$ Center of Environmental and Sustainable Sciences, Directorate of Research, Community Services and Innovation, Universitas Padjadjaran. J1. Sekeloa, \\ Coblong, Bandung 40132, West Java, Indonesia
}

Manuscript received: 6 October 2021. Revision accepted: 5 November 2021.

\begin{abstract}
Nuriyah S, Husodo T, Hermawan W, Yusuf AA, Kasmara H, Kusmoro J, Wulandari I, Shanida SS. 2021. Short Communication: Floral diversity of honey bee-collected pollen (Apis cerana) colonies in the Ir. H. Djuanda Forest Park, West Jawa, Indonesia. Nusantara Bioscience 13: 185-193. Honey bees, especially Apis cerana Fabr., need feed sources from nectar and pollen. In addition, pollen is essential for sexual reproduction. However, various plants in the forest park have not been supported by information on pollinated plants or as feed sources by A. cerana. Therefore, this study should be conducted as essential information to reveal the pollens as feed sources of $A$. cerana in the Ir. H. Djuanda Forest Park, West Java. However, there is little information about those plants in the forest park, West Java. Therefore, this study aimed to reveal the pollens as feed sources of A. cerana in the Ir. H. Djuanda Forest Park. Sampling was collected on 45 honey bee-collected pollen from three cultivation areas. Pollen preparation was carried out using the acetolysis method. Based on the study results, 70 species of pollen flora of 36 families were found in Ir. H. Djuanda Forest Park vegetation in the A. cerana. However, further study is needed regarding the frequently visited plants used as feed sources or pollinating by A. cerana. In addition, considering that the honey bees cultivated in the forest park are dominated by A. cerana, further studies are needed on regularly pollinated plants to maximize the yield of honey cultivation.
\end{abstract}

Keywords: Apis cerana, Ir. H. Djuanda Forest Park, pollen

\section{INTRODUCTION}

Pollination is a vital ecological service provided by many insects, such as flies, wasps, bees, butterflies, beetles, and moths (Tumminelo et al. 2017). Pollination permits plant reproduction, which provides seeds, fruit, and leaves consumed by humans throughout the globe (Eeraerts et al 2020). Without these services, it is feared that many interconnected processes in an ecosystem would collapse (Ollerton et al. 2011). Various pollination sources include insects, wind, air, rain, humans, animals, and birds (Delaplane et al. 2013). Insect pollinators are indispensable in pollinating food crops (Akhtar et al. 2018). Diptera, Hymenoptera, Lepidoptera, and Coleoptera can deliver an essential ecosystem service of pollination, which is vital for maintaining wild plants and crop communities (Noriega et al. 2018).

Asian honey bees, Apis cerana Fabr., are from southern and south-eastern Asia with various subspecies found in different Asian countries, including Indonesia (Hyatt 2012), e.g., A. cerana javana. Apis cerana is an excellent pollinator of many crops that improves quality and quantity (Pudasaini 2014; Pudasaini and Thapa 2014a). Similarly, A. cerana is an efficient pollinator compared to A. mellifera and $A$. dorsata in natural conditions (Pudasaini and Thapa 2014b). The pollination mechanism is formed from symbiotic interactions between flowering plants and animals (Gill et al. 2016). When plants receive pollination services, honey bees get energy and protein sources from nectar and pollen. Nectar is the source of carbohydrates, primarily energy, and pollen is the primary source of protein, fats, minerals, and vitamins (Nicolson 2011). Pollen and nectar are honey bee feed sources from flowering plants around their beehive to fulfill their daily needs (Keller et al. 2015). Pollen is a crucial component in pollination because, without pollen, the sexual reproduction of various flowering plants will not occur (Garibaldi et al. 2014). Therefore, maintaining honey bees is very useful for multiple flower pollination services, and it could get products such as honey, propolis, royal jelly, and bee wax (Sihag and Gupta 2011).

The knowledge of bees' biology and ecological behavior is essential in apiculture, which helps understand the associated problems and management (Aryal 2019). Also, the ability of honey bee nutrition is necessary to successfully manage issues that may occur in the apiary (Somerville 2005). The previous studies had been conducted in Indonesia. Yolanda et al. (2020) studied the diversity and character of pollen as A. cerana feed sources in Serang Purbalingga, Central Java. They sampled the 
honeycomb and fresh flowers around the honeycomb. Sudarmono (2019) studied pollen diversity from the fresh flower in the Bogor Botanical Garden, West Java. Salamah et al. (2019) only studied the pollen morphology of Asteraceae from a fresh flower in Depok, West Java. Mursyidin et al. (2018) only studied the pollen diversity of the Oryza sativa cultivars in the South Kalimantan. Widowati et al. (2013) and Widowati et al. (2020) studied the effect of pollen substitutes on the productivity of $A$. cerana in Bandung, West Java. Pollen substitutes can increase the productivity of $A$. cerana. Hidayati et al. (2020) studied pollen diversity in Apis spp. and stingless bee honey in Boyolali District, Central Java. Kviesis et al. (2020) studied temperature and weight monitoring of the $A$. cerana bee colony using the SAMS monitoring devices in the Madu Maribaya Apiary Ir. H. Djuanda Forest Park, West Java. They found that temperature and weight monitoring can be used for remote bee colony monitoring and is essential for reliable colony temperature collection. Nuriyah et al. (2021) studied about ecosystem services of A. cerana in the Ir. H. Djuanda Forest Park. They found 83 species of 39 families as feed sources of $A$. cerana in three honey bee cultivations. Thus, A. cerana provides ecosystem services to the sustainability of Ir. H. Djuanda Forest Park.
Those studies revealed pollen diversity of $A$. cerana from fresh pollen and or honeycomb. However, the study of pollen diversity from corbicular pollen is still lacking, so this study should be conducted to reveal the feed sources of $A$. cerana. It is essential to understand the plant diversity as pollen sources of $A$. cerana so that beekeepers can make appropriate and informed management decisions. Also, this study must be conducted as basic information and be the latest information about the pollens in West Java, Indonesia. According to the introduction, this study investigates the floral diversity of honey bee-collected pollens in managed $A$. cerana colonies in Ir. H. Djuanda Forest Park, West Java, Indonesia.

\section{MATERIALS AND METHODS}

\section{Study area}

Ir. H. Djuanda Forest Park is located $107^{\circ} 30^{\prime} 00^{\prime \prime}$ E and $6^{\circ} 52^{\prime} 00^{\prime \prime} \mathrm{S}$, approximately $7 \mathrm{~km}$ from downtown Bandung District, West Java, Indonesia. The Forest Park is located in Cikapundung Sub-watershed and the Citarum watershed, stretching from Curug (Waterfall) Dago, Dago Pakar, and Curug Maribaya. The detail of the study area can be seen in Figure 1.

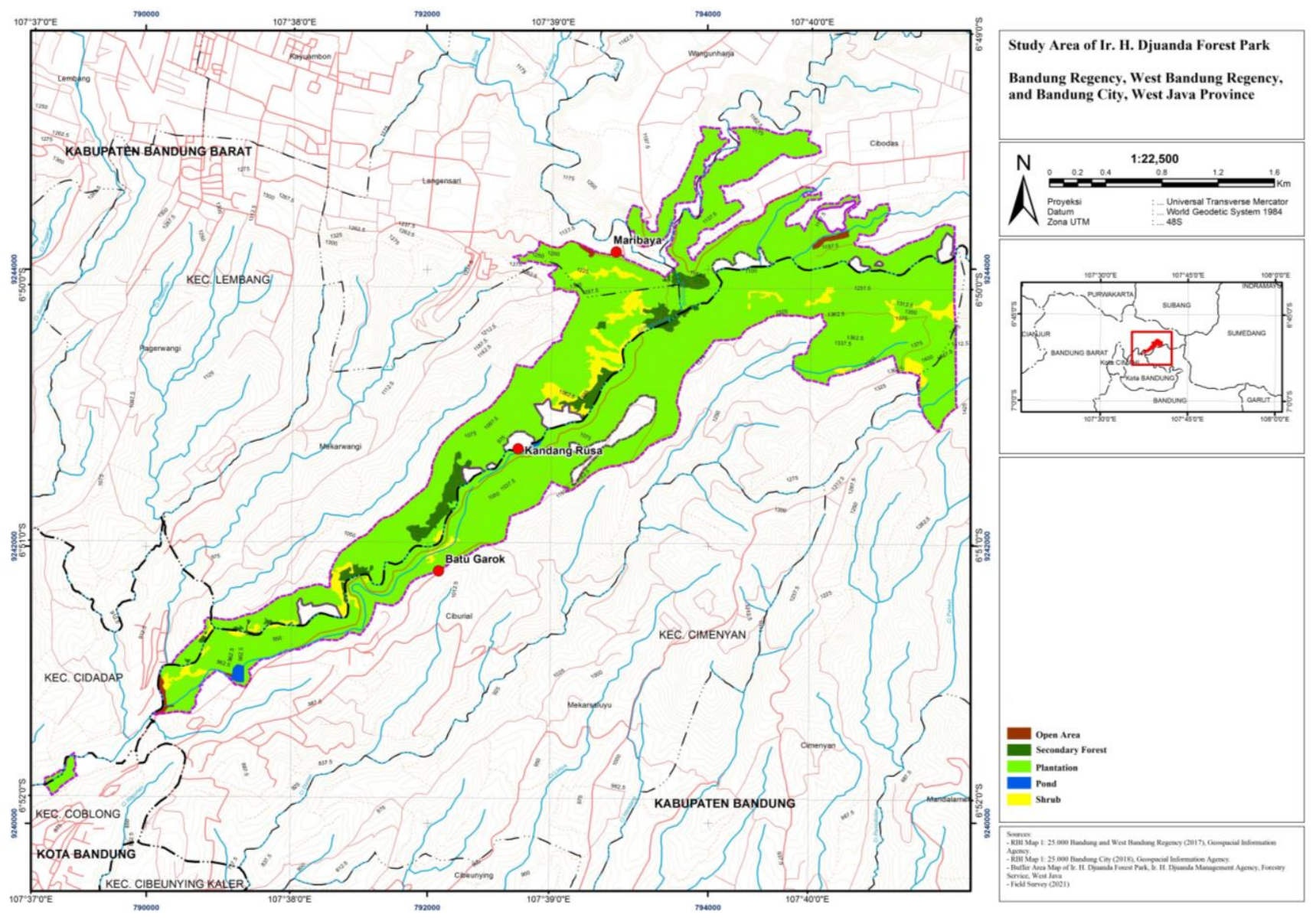

Figure 1. The study area in Batu Garok (6 $\left.51^{\prime} 24.55^{\prime \prime S} 107^{\circ} 37^{\prime} 44.93 " E\right)$, Deer Captive Breeding (Penangkaran Rusa) (6 50 '37.33"S $\left.107^{\circ} 38^{\prime} 59.88^{\prime \prime E}\right)$, and Maribaya (6 $6^{\circ} 0^{\prime} 7.25^{\prime S}$ 107 $\left.399^{\prime} 30.23 " E\right)$, Ir. H. Djuanda Forest Park, Bandung District, West Java, Indonesia 
Administratively, Ir. H. Djuanda Forest Park is located in Ciburial Village, Cimenyan Sub-district, Bandung District, and parts of the area in Mekarwangi Village, Cibodas Village, Langensari Village, and Wangunharja Village, Lembang Sub-district, West Bandung District and Dago Village, Coblong Bandung Sub-district, Indonesia (Ir. H. Djuanda Forest Park Management Center 2019). Ir. H. Djuanda Forest Park has an area of 528,393 hectares with a land cover dominated by plantation forests of 475,158 hectares. Other land cover types are secondary forest covering an area of 19,652 hectares, shrubs covering an area of 29,558 hectares, ponds covering an area of 1,187 hectares, and open areas of 2,838 hectares.

Ir. H. Djuanda Forest Park is part of the Bandung basin area, with a historical background intimately related to ancient times (Ervinal et al. 2020). Ir. H. Djuanda Forest Park has become a protected area whose space is used for tourism activities. The Local Government also supports spatial utilization in the North Bandung area set out in the West Java Provincial Act No. 25 of 2008 about the Management of Ir. H. Djuanda Forest Park, that tourism is one of the activities in the protected area of North Bandung (Arief 2013).

\section{Procedures \\ Hand-collection}

The study was conducted in August 2021 in the three cultivation areas, including Maribaya, Batu Garok, and Deer Breeding (Penangkaran Rusa). Three colonies were selected for each cultivation area. The A. cerana used is an individual that carried pollen on the hind legs (corbiculae) compacted in the pollen sac. We took five honey beecollected pollen per colony. Thus, the number of honey bees used in the sampling was 15 individuals in each cultivation area. A total of 45 individuals of $A$. cerana (from three cultivation areas) were sampled. Sampling was conducted by catching them with tweezers directly when they wanted to enter the hive. Each sample was put into separate papillote paper. We separated each sample (corbiculae) to avoid contamination.

\section{Acetolysis method}

Pollen identification is more accurate using the acetolysis method (Jones 2014). The acetolysis method is the standard method in palynological preparation. This method is also indispensable for illustrating pollen grains through light microscopy. Stained pollen grains will cover the visuals of the pollen grains, making it difficult to provide an overview of the pollen grains. The acetolysis process removes the cellular wall and the intine and destroys the aperture membrane. In addition, cleaning the surface of the pollen grain and coloring the pollen can make it easier for researchers to observe all the details of the pollen grain wall (Erdtman, 1960). The Acetolysis method is a combination method between chlorination and acetylation procedures (Hesse et al. 2009).

During the Chlorination stage, pollen was put into a centrifugation tube, added with 98\% Glacial Acetic Acid (AAG), and 3-4 drops of $\mathrm{HCl}$ were then stirred using a glass rod to mix evenly. The pollen was heated using a water bath for three minutes. After heating, the pollen was centrifuged at 2,000-3,000 rpm for 10 minutes. Centrifugation served to precipitate pollen grains, making it easy to separate pollen grains from dirt when changing liquids (Sudarmono and Sahromi 2012). The supernatant was removed slowly for the pollen deposits were not wasted, and the residue was washed with distilled water. It was centrifuged again at 2,000-3,000 rpm for two minutes. Washing was carried out three times to remove AAG.

During Acetylation Stage, a mixture of $98 \%$ AAG and sulfuric acid in a ratio of 9:1 was dropped into the tube. After that, it was heated to $100^{\circ} \mathrm{C}$ for four minutes. The pollen was centrifuged at 2,000-3,000 rpm for 10 minutes. The supernatant was removed slowly for the pollen deposits were not wasted, and the residue was washed with distilled water. It was centrifuged again at 2000-3000 rpm for two minutes. Washing was done three times to remove the mixture of AAG and sulfuric acid.

After the acetolysis method, the pollen samples were stored in wet preservation. The sample was stored in a 20 cc vial and added to distilled water. According to Halbritter (2018), dry and fresh pollen must be hydrated with water to obtain a good quality pollen grain, ensuring that the pollen grains are not damaged or contaminated with fungi. Each vial was labeled with a label.

Then, the sample was stored in the refrigerator; if the samples were observed and identified, samples from wet preservation were taken as much as 1-2 drops on an object glass and added one drop of glycerin. According to Halbritter (2018), it should be observed as soon as possible after being given glycerin because the pollen grains will expand in a few days or weeks. Then, the sample was covered with a cover glass. Nail polish was applied to the edges of the cover glass to avoid shifting the cover glass. After that, the microscope slide was dried on a hotplate and labeled on the microscope slide on each sample. We use the guidelines to identify pollen, such as Erdtman (1969) and Faegri and Iversen (1989). The parameters in identifying pollen, namely family, species, and pollen form (pollen unit, pollen size category, pollen size $(\mu \mathrm{m})$, and ornamentation type). Pollen measurement was carried out based on the size of the longest axis, which was divided into six sizes, namely very small: $<10 \mu \mathrm{m}$, small: $10-25$ $\mu \mathrm{m}$, medium: $25-50 \mu \mathrm{m}$, large: $50-100 \mu \mathrm{m}$, very large: $100-$ $200 \mu \mathrm{m}$, and giant: $>200 \mu \mathrm{m}$.

\section{Data analysis}

The data were analyzed in Microsoft Excel and tabulated in the table. The results were described qualitatively.

\section{RESULTS AND DISCUSSION}

Based on the study results, 70 species of pollen from 36 families were found (Table 1). Some pictures of pollen grains found during the identification can be seen in Figure 2. Some plants in the Ir. H. Djuanda Forest Park are found in the corbiculae of $A$. cerana. Table 1 shows that some plants can be found in plantation forests, secondary forests, and shrubs in Ir. H. Juanda Forest Park. In general, the 
pollen identified was dominated by pollen units of monads, while the others were found in polyads and tetrads. Based on the size category, pollen ranged from very small to large.

Suwannapong et al. (2013) identified pollen from the $A$. cerana midgut recorded as many as 25 species in Northern Thailand. They found that the favored pollen source plant of A. cerana was Mimosa pudica. Mimosa pudica is widely distributed throughout the year and has a relatively high protein concentration in its pollen, so $M$. pudica becomes a favored feed source for $A$. cerana. Furthermore, the amount and diversity of pollen in honey are usually related to vegetation, climate, and geographical location of beehives. Therefore, the pollen composition of the honey studied reveals essential information on that region's flora (Cherian et al. 2011).

We assumed that the pollen flora in the corbiculae is plants that live 100 - 500 meters from nests (Hyat 2012).
Still, their foraging ability will decrease if the desired feed is unavailable nearby. Pudasaini and Thapa (2014b) said that honey bees would approach the feed source habitat closer to the nest for energy effectiveness and efficiency. According to Partap and Yang (2012), the foraging behavior of honey bees leads to ecosystem services in plant pollination influenced by several factors, including nectar content, odor, color, and flower shape. Regarding foraging performance, the higher numbers of foraging trips of $A$. cerana than A. mellifera could be due to their shortage of foraging distance (He et al. 2013; Koetz 2013) or better learning and memory for color and grating patterns (Qin et al. 2012), or both. With more foraging trips, A. cerana will increase the amount of nectar brought into the colonies when all other conditions are equal. However, A. mellifera carries heavier nectar loads than A. cerana (Tan et al. 2012).

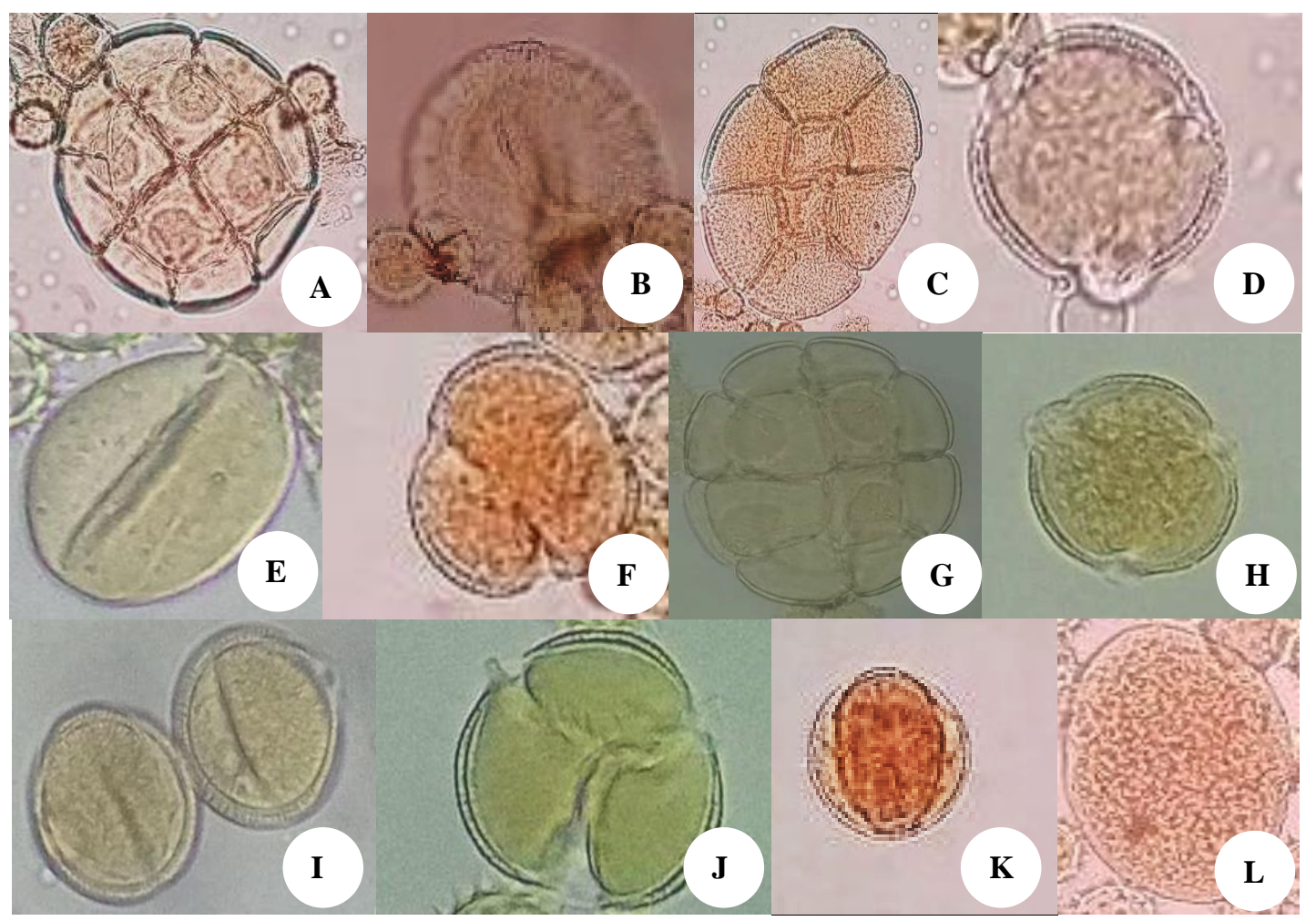

Figure 2. Some pollen grains were found during observation. A. Acacia mangium Willd., B. Cinnamomum burmanni (Nees \& T.Nees) Blume, C. Calliandra calothyrsus Meisn., D. Lantana camara L., E. Michelia champaca L., F. Calophyllum soulattri Burm.f., G. Cassia alata L., H. Capsicum frutescens L., I. Globa pendula Roxb., J. Saxifraga stolonifera Curtis, K. Castanopsis argentea (Blume) A.DC., L. Plantago major L. (Primary Data 2021) 
Table 1. The pollens in the corbiculae of Apis cerana, Ir. H. Djuanda Forest Park, West Java, Indonesia

\begin{tabular}{|c|c|c|c|c|c|}
\hline \multirow{3}{*}{ Family | Species } & \multirow{3}{*}{ Local name } & \multicolumn{4}{|r|}{ Pollen morphology } \\
\hline & & \multirow{2}{*}{ Unit } & \multicolumn{2}{|c|}{ Size } & \multirow{2}{*}{ Ornamentation } \\
\hline & & & Category & $\mu \mathrm{m}$ & \\
\hline \multicolumn{6}{|l|}{ Acanthaceae } \\
\hline Pachystachys lutea Nees & Bunga lilin & Monad & Large & $51-100$ & Reticulate, Tricolporate \\
\hline \multicolumn{6}{|l|}{ Anacardiaceae } \\
\hline Mangifera indica $\mathrm{L}$. & Mangga & Monad & Small & $0.75-1.33$ & Reticulate, Monocolpate \\
\hline Mangifera foetida Blume & Mangga bacang & Monad & Small & $0.75-1.34$ & Reticulate \\
\hline \multicolumn{6}{|l|}{ Arecaceae } \\
\hline Arenga pinnata (Wurmb) Merr. & Aren & Monad & Medium & $26-50$ & Sulcate \\
\hline \multicolumn{6}{|l|}{ Asteraceae } \\
\hline Helianthus annuus L. & Bunga matahari & Monad & Medium & $26-50$ & Spheroidal, Tricolporate \\
\hline Ageratum conyzoides $\mathrm{L}$. & Babadotan & Monad & Small & $10-25$ & Spheroidal, Tricolporate \\
\hline Acmella paniculata (Wall. ex DC.) & Jotang & Monad & Medium & $26-50$ & Spheroidal, Tricolporate \\
\hline Bidens pilosa $\mathrm{L}$. & Ketul & Monad & Small & $10-25$ & Spheroidal, Tricolporate \\
\hline \multicolumn{6}{|l|}{ Balsamiaceae } \\
\hline Impatiens balsamina $\mathrm{L}$. & Pacar air & Monad & Medium & $26-50$ & Spheroidal, Tricolporate, Reticulate \\
\hline \multicolumn{6}{|l|}{ Bignoniaceae } \\
\hline Kigelia aethiopica Decne. & Pohon Sosis & Monad & Large & $51-100$ & Spheroidal, Tricolpate, Reticulate \\
\hline Jacaranda filicifolia D.Don & Jakaranda ungu & Monad & Medium & $26-50$ & Shperoidal, Tricolporate \\
\hline \multicolumn{6}{|l|}{ Brassicaceae } \\
\hline Brassica juncea (L.) Czern. & Sawi hijau & Monad & Medium & $26-50$ & Shperoidal, Tricolpate, Reticulate \\
\hline Brassica oleracea L. & Sawi putih & Monad & Medium & $26-30$ & Prolate, Tricolpate, Reticulate \\
\hline \multicolumn{6}{|l|}{ Caesalpiniaceae } \\
\hline Tamarindus indica $\mathrm{L}$. & Asam Jawa & Monad & Large & 90 & Oblate-spheroidal, Striato-reticulate, Tricolporate \\
\hline Caesalpinia pulcherrima (L.) Sw. & Kembang merak & Tetrad & Medium & $26-50$ & Inarpertura, Tricolporate, Psilate \\
\hline \multicolumn{6}{|l|}{ Calophyllaceae } \\
\hline Calophyllum soulattri Burm.f. & Bintangur/Sulatri & Monad & Medium & $26-50$ & Spheroidal, Tricolporate, Reticulate \\
\hline \multicolumn{6}{|l|}{ Cannabaceae } \\
\hline Trema amboinensis (Willd.) Blume & Mengkiray & Monad & Medium & $26-50$ & Spheroidal, Stephanoarperturate \\
\hline \multicolumn{6}{|l|}{ Convolvulaceae } \\
\hline Ipomoea quamoclit $\mathrm{L}$. & Rincik bumi & Monad & Large & $>100$ & Spheroidal, Pantoporate, Radial Symmetry \\
\hline \multicolumn{6}{|l|}{ Cucurbitaceae } \\
\hline Cucumis sativus L. & Mentimun & Monad & Large & $51-100$ & Oblate-spheroidal, Trizonoporate, Faintly reticulate \\
\hline \multicolumn{6}{|r|}{ 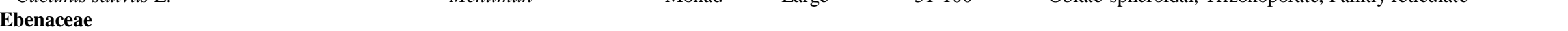 } \\
\hline Diospyros discolor Willd. & Bisbul & Monad & Medium & $41-50$ & Tricolporate, Reticulate, Psilate \\
\hline \multicolumn{6}{|l|}{ Euphorbiaceae } \\
\hline Ricinus communis $\mathrm{L}$. & Jarak pagar & Monad & Medium & $26-50$ & Prolate-spheroidal, Tricolporate, Reticulate, Bilateral symmetry \\
\hline Euphorbia pulcherrima Willd. Ex Klotzsch & Bunga euphorbia & Monad & Medium & $26-50$ & Prolate-spheroidal, Tricolporate, Reticulate \\
\hline
\end{tabular}




\begin{tabular}{|c|c|c|c|c|c|}
\hline \multicolumn{6}{|l|}{ Fabaceae } \\
\hline Delonix regia (Bojer ex Hook.) Raf & Flamboyan & Monad & Large & $51-100$ & Prolate-spheroidal, Tricolporate, Reticulate \\
\hline Leucaena leucocephala (Lam.) de Wit & Lamtoro & Monad & Large & $51-100$ & Spheroidal, Tricolporate, \\
\hline Glycine $\max (\mathrm{L}$.$) Merr.$ & Kedelai & Monad & Small & $21-25$ & Spheroidal, Tricolporate, Psilate \\
\hline Gliricidia sepium (Jacq.) Kunth & Gamal & Monad & Medium & $26-50$ & Spheroidal, Tricolporate, Psilate \\
\hline Erythrina subumbrans (Hassk.) Merr. & Dadap & Monad & Medium & $26-50$ & Oblate, Tricolpate, Reticulate \\
\hline Calliandra calothyrsus Meisn. & Kaliandra merah & Polyad & Very Large & $>100$ & Sub-Oblate, Porate \\
\hline Acacia mangium Willd. & Akasia & Polyad & Medium & 42.93-44.99 & Tetracolporate, Psilate \\
\hline Albizia chinensis (Osbeck) Merr. & Sengon/Albasia & Polyad & Large & $51-100$ & Quadrangular, Inarperturate, Psilate \\
\hline Cassia siamea Lam. & Johar & Polyad & Large & 92,85 & Oblate-spheroidal, Tricolporate \\
\hline Albizia sp. & - & Polyad & Medium & $26-50$ & Inaperturate, Psilate \\
\hline Cassia alata $\mathrm{L}$. & Daun ketepeng Cina & Polyad & Large & 125 & Sub-prolate, Tricalporate \\
\hline Mimosa pudica L. & Putri malu & Tetrad & Very Small & $<10$ & Oblate, inaperturate, Psilate \\
\hline \multicolumn{6}{|l|}{ Fagaceae } \\
\hline Castanopsis argentea (Blume) A.DC. & Saninten & Monad & Small & $10-15$ & Prolate, Tricolporate, Psilate \\
\hline \multicolumn{6}{|l|}{ Gnetaceae } \\
\hline Gnetum gnemon L. & Melinjo & Monad & Small & $10-25$ & Inarperturate, Microechinate \\
\hline \multicolumn{6}{|l|}{ Lamiaceae } \\
\hline Gmelina arborea Roxb. ex Sm. & Jati putih & Monad & Medium & $26-50$ & Prolate-spheroidal, Tricolpate, Reticulate \\
\hline Ocimum x citriodorum Vis. & Kemangi & Monad & Large & $51-100$ & Hexacolpate, Reticulate, Radial symmetry \\
\hline \multicolumn{6}{|l|}{ Lauraceae } \\
\hline Persea americana Mill. & Alpukat & Monad & Medium & $26-50$ & Spheroidal, Inarperturate, Microechinate \\
\hline Cinnamomum parthenoxylon (Jack) Meisn. & Ki Pedes/ Ki sereh & Monad & Medium & $26-50$ & Prolate-spheroidal, Inarperturate, Microechinate \\
\hline Cinnamomum burmanni (Nees \& T.Nees) Blume & Kayu manis & Monad & Medium & $26-50$ & Prolate-spheroidal, Inarperturate, Microechinate \\
\hline \multicolumn{6}{|l|}{ Lythraceae } \\
\hline Lagerstroemia speciosa (L.) Pers. & Bungur & Monad & Medium & $26-50$ & Tricolporate, Fossulate \\
\hline \multicolumn{6}{|l|}{ Magnoliaceae } \\
\hline Michelia champaca $\mathrm{L}$. & Manglid/ cempaka & Monad & Large & $51-100$ & Oblate, Sulcate, Scabrate \\
\hline \multicolumn{6}{|l|}{ Malvaceae } \\
\hline Hibiscus rosa-sinensis $\mathrm{L}$. & Bunga sepatu & Monad & Large & 100 & Pantoporate, Radial Symetry \\
\hline Sida rhombifolia $\mathrm{L}$. & Sidaguri & Monad & Large & $51-100$ & Pantoporate, Echinate, Radial symmetry \\
\hline Urena lobata $\mathrm{L}$. & Pulutan & Monad & Medium & 35 & Oblate, Panto porate \\
\hline Ceiba pentandra (L.) Gaertn. & Kapuk randu & Monad & Large & $60-80$ & Tricolpate, Reticulate \\
\hline Salmalia malabarica (DC.) Schott \& Endl. & Dangdeur & Monad & Large & $51-100$ & Oblate, Tricolpate, Reticulate \\
\hline Durio zibethinus L. & Durian & Monad & Large & $68-69$ & Triporate, Spheroidal \\
\hline \multicolumn{6}{|l|}{ Melastomataceae } \\
\hline Melastoma malabathricum $\mathrm{L}$. & Harendong bulu & Monad & Small & $16-20$ & Prolate-spheroidal, Tricolporate, Radial symmetry \\
\hline \multicolumn{6}{|l|}{ Muntingiaceae } \\
\hline Muntingia calabura $\mathrm{L}$. & Kersen & Monad & Small & $10-25$ & Prolate-spheroidal, Tricolporate, Reticulate \\
\hline \multicolumn{6}{|l|}{ Myrtaceae } \\
\hline Syzygium aqueum (Burm.f.) Alston & Jambu air & Monad & Small & $10-25$ & Tricolporate, Psilate \\
\hline \multicolumn{6}{|l|}{ Phyllanthaceae } \\
\hline Antidesma bunius (L.) Spreng & Huni & Monad & Small & 18 & Tricolporate \\
\hline
\end{tabular}




\begin{tabular}{|c|c|c|c|c|c|}
\hline \multicolumn{6}{|l|}{ Pineaceae } \\
\hline Pinus merkusii Jungh. \& de Vriese & Pinus & Monad & Large & $50-60$ & Reticulate, Vesiculate \\
\hline \multicolumn{6}{|l|}{ Plantaginaceae } \\
\hline Plantago major $\mathrm{L}$. & Daun sendok & Monad & Small & $10-25$ & Porate-spherodial, Pantopertura \\
\hline \multicolumn{6}{|l|}{ Rubiaceae } \\
\hline Coffea arabica $\mathrm{L}$. & Kopi arabika & Monad & Medium & $26-50$ & Oblate-spheroidal, Bilateral Symmetry, Tricolporate \\
\hline Anthocephalus cadamba (Roxb.) Miq. & Jabon & Monad & Small & $10-25$ & Sheroidal, Tricolporate \\
\hline \multicolumn{6}{|l|}{ Rutaceae } \\
\hline $\begin{array}{l}\text { Murraya paniculata (L.) Jack } \\
\text { Saxifragaceae }\end{array}$ & Kamuning & Monad & Medium & $31-35$ & Tricolporate, Striate \\
\hline Saxifraga stolonifera Curtis & Kuping macan & Monad & Small & $10-25$ & Oblate, Tricolpate, Striate \\
\hline \multicolumn{6}{|l|}{ Solanaceae } \\
\hline Capsicum aпnиum $\mathrm{L}$. & Cabai besar & Monad & Medium & $26-50$ & Spheroidal porate, Tricolporate, Scabrate \\
\hline Solanum lycopersicum $\mathrm{L}$. & Tomat & Monad & Small & $10-25$ & Spheroidal, Tricolporate, Psilate \\
\hline Solanum melongena $\mathrm{L}$. & Terung ungu & Monad & Small & $10-25$ & Prolate-spheroidal, Psilate, Bilateral symmetry \\
\hline Capsicum frutescens $\mathrm{L}$. & Cabai rawit & Monad & Medium & $26-51$ & Prolate-spheriodal, Tricolpate \\
\hline \multicolumn{6}{|l|}{ Theaceae } \\
\hline Camellia sinensis (L.) Kuntze & Teh & Monad & Medium & $26-50$ & Triangular, Tricolporate, Verrucate \\
\hline Schima wallichii (DC.) Korth. & Puspa & Monad & Medium & $26-50$ & Prolate, Tricolporate, Reticulate \\
\hline \multicolumn{6}{|l|}{ Typhaceae } \\
\hline Typha angustifolia $\mathrm{L}$. & Lembang & Tetrad & Medium & $36-50$ & Spheroidal, Ulcerate, Reticulate \\
\hline \multicolumn{6}{|l|}{ Urticaceae } \\
\hline Laportea interrupta (L.) Chew & Jelatang ayam & Monad & Small & $11-15$ & Spheroidal, Triporate, Granulate \\
\hline \multicolumn{6}{|l|}{ Verbenaceae } \\
\hline Lantana camara $\mathrm{L}$. & Tahi ayam & Monad & Medium & $41-50$ & Colporate-spheroidal, Tricolporate, Psilate \\
\hline \multicolumn{6}{|l|}{ Zingiberaceae } \\
\hline Zingiber inflexum Blume & Jahe-jahean & Monad & Large & $51-100$ & Spheroidal, Inaperturate, Areolate \\
\hline Globa pendula Roxb. & Pedas kancil & Monad & Large & $51-100$ & Spheroidal, Inaperturate, Echinate \\
\hline
\end{tabular}


In conclusion, some plants in the Ir. H. Djuanda Forest Park vegetation are also found in the corbiculae of $A$. cerana. However, further study is needed regarding the frequently visited plants by $A$. cerana and plants used as feed sources or pollinating. It is essential to reveal how $A$. cerana meets pollen and nectar needs throughout the year in Djuanda Forest Park, given that the flowering period of each plant is different. In addition, considering that the honey bees cultivated in Djuanda Forest Park are dominated by $A$. cerana, further studies are needed on regularly pollinated plants to maximize the yield of honey cultivation. This follow-up study can be used as information in honey bee management. Beekeepers and managers of Djuanda Forest Park can conserve plants pollinated by A. cerana in Djuanda Forest Park.

We recommend nutritional analysis of pollens and longerterm studies, as this study only covers a month. In addition, the phenology of flowering plants of importance to honey bees is highly diverse spatially and temporally. Therefore, beekeepers need better support to understand the floral resources in their operational range and to provide advice on how to protect and increase the availability of these plants for bees. Also, the beekeepers should understand how to implement appropriate supplementary feeding and manage honey bees during dearth periods using data initiated through this study.

\section{ACKNOWLEDGEMENTS}

Special thanks to the Ministry of Research, Technology and Higher Education of Indonesia and Directory Research, Community Services, and Innovation of Universitas Padjadjaran, Indonesia, which provides financial support under Penelitian Dasar Unggulan Perguruan Tinggi (PDUPT), the experts, and the surveyor team. Thanks to the staff and beekeepers of the Ir. H. Djuanda Forest Park Management Center, Bapak Ganjar, Ir. H. Djuanda Forest Park Management Center.

\section{REFERENCES}

Akhtar T, Aziz MA, Naeem M, Ahmed MS, Bodlah I. 2018. Diversity and relative abundance of pollinator fauna of canola (Brassica napus L. Var Chakwal Sarsoon) with managed Apis mellifera L. in Pothwar Region, Gujar Khan, Pakistan. Pak J Zool 50 (2): 567-573. DOI: 10.17582/journal.pjz/2018.50.2.567.573.

Arief AMR. 2013. Development of tourism activities in the Djuanda Fores Park, Bandung, West Java. Jurnal Sorot 8 (2): 167-182. DOI: 10.31258/sorot.8.2.2360. [Indonesian]

Aryal B. 2019. Migratory behavior of Apis cerana. Res Rev J Crop Sci Technol 8 (3): 1-5.

Cherian KJ, Bhowal M, Godghate SD. 2011. Pollen and physicochemica analysis of honey produced by Apis cerana indiva of Nagpur, Maharashtra (India). J Environ Res Develop 5 (3): 542-550.

Delaplane KS, Dag A, Danka RG, Freitas BM, Garibaldi LA, Goodwin RM, Hormaza JI. 2013. Standard methods for pollination research with Apis mellifera. J Apic Res 52: 1-28. DOI: 10.3896/IBRA.1.52.4.12.

Djuanda Forest Park Management Center. 2019. Overview of Ir. H. Djuanda Forest Park, West Java. https://tahuradjuanda.jabarprov.go.id/. [Indonesian]

Eeraerts M, Smagghe G, Meeus I. 2020. Bumble bee abundance and richness improves honey bee pollination behaviour in sweet cherry. Basic Appl Ecol 43: 27-33. DOI: 10.1016/j.baae.2019.11.004.
Erdtman G. 1960. The acetolysis method. A revised description. Svensk Botanisk Tidskrift 54: 561-564.

Erdtman G. 1969. Handbook of Palynology. Morphology - Taxonomy Ecology. An Introduction to the Study of Pollen Grains and Spores. Leinen D. kr, Preis. DOI: 10.1002/fedr.19710810815.

Ervinal E, Wulung SRP, Octaviany V. 2020. Tourist perception of visitor management strategy in North Bandung Protected Area. J Bus Hosp Tour 6 (2): 303-314. DOI: 10.22334/jbhost.v6i2.

Faegri K, Iversen J. 1989. Textbook of Pollen Analysis (4th). John Wiley \& Sons Ltd, Chichester, UK.

Garibaldi LA, Carvalheiro LG, Leonhardt SD, Aizen MA, Blaauw, BR, Isaacs R, Kuhlmann M, Kleijn D, Klein AM, Kremen C, Morandin L, Scheper J, Winfree R. 2014. From research to action: Enhancing crop yield through wild pollinators. Front Ecol Environ 12 (8): 39-447. DOI: $10.1890 / 130330$

Gill RJ, Baldock KCR, Brown MJF, Cresswell JE, Dicks LV, Fountain MT, Garratt MPD, Gough LA, Heard MS, Holland JM, Ollerton J, Stone GN, Tang CQ, Vanbergen AJ, Vogler AP, Woodward G, Arce AN, Boatman ND, Brand-Hardy R, Breeze TD, Green M, Hartfield CM, O'Connor RS, Osborne JL, Phillips J, Sutton PB, Potts SG. 2016. Protecting an ecosystem service: Approaches to understanding and mitigating threats to wild insect pollinators. J Adv Ecol Res 54: 135-206. DOI: 10.1016/bs.aecr.2015.10.007.

Halbritter H, Ulrich S, Grímsson F, Weber M, Zetter R, Hesse M, Buchner R, Svojtka M, Frosch-Radivo A. 2018. Illustrated Pollen Terminology. Springer, Vienna, Austria.

Hesse M, Halbritter H, Zetter R, Weber M, Buchner R, Frosch-Radivo A, Ulrich S. 2009. Pollen Terminology. An Illustrated Handbook. Springer, Vienna, Austria.

Hidayati N, Suedy SWA, Darmanti S. 2020. Identification of pollen diversity as feed source plant of local bees in five villages in Boyolali District. Majalah Ilmiah Biologi Biosfera 37 (1): 36-42. DOI: 10.20884/1.mib.2020.37.1.1073. [Indonesian]

Hyatt S. 2012. Asian Honey Bee (Apis cerana javana) in Cairns, Far North Queensland Foraging, Nesting and Swarming Behavior Report of Field Observations April 2007-September 2011. Department of Employment, Economic Development and Innovation, Queensland, Australia.

Jones GD. 2014. Pollen analyses for pollination research, acetolysis. J Pollinat Ecol 13 (21): 203-217. DOI: 10.26786/1920-7603(2014)19.

Koetz AH. 2013. Ecology, behaviour and control of Apis cerana with a focus on relevance to the Australian incursion. Insects 4 (4): 558-592. DOI: 10.3390/insects4040558.

Kviesis A, Zacepins A, Komasilovs V, Paramita AM, Muhammad FR. 2020. Temperature and weight monitoring of the Apis cerana bee colony Indonesia. Rural Sustain Res 44 (339): 54-60. DOI: 10.2478/plua-20200017.

Mursyidin DH, Sumardi I, Purnomo, Daryono BS. 2018. Pollen diversity of the tidal swamp rice (Oryza sativa L.) cultivars collected from South Kalimantan, Indonesia. Aust J Crop Sci 12 (3): 380-385. DOI: 10.21475/ajcs.18.12.03.pne751.

Nicolson SW. 2011. Bee Food: The chemistry and nutritional value of nectar, pollen and mixtures of the two. Afr Zool 46 (2): 197-204. DOI: 10.3377/004.046.0201

Noriega JA, Hortal J, Azcarate FM, Berg MP, Bonada N, Briones MJI, Del Toro I, Goulson D, Ibanez S, Landis DA, Moretti M, Potts SG, Slade EM, Stout JC, Ulyshen MD, Wackers FL, Woodcock BA, Santos AMC. 2018. Research trends in ecosystem services provided by insects. Basic Appl Ecol 26: 8-23. DOI: 10.1016/j.baae.2017.09.006.

Nuriyah S, Yusuf AA, Hermawan W, Husodo T. 2021. Ecosystem services from honey beees Apis cerana Fabr. Taman Hutan Raya (Tahura) Ir. H. Djuanda Dago Expert Bandung Ecology and Economically. E3S Web Conf 249 (2): 03016. DOI: 10.1051/e3sconf/202124903016.

Ollerton J, Winfree R, Tarrant S. 2011. How many flowering plants are pollinated by animals. Oikos 120 (3): 321-326. DOI: 10.1111/j.16000706.2010.18644.x.

Partap U, Yang T. 2012. The human pollinators of fruit crops in Maoxian County, Sichuan, China. Mt Res Dev 322 (2): 176-186. DOI: 10.1659/MRD-JOURNAL-D-11-00108.1.

Pudasaini R, Thapa RB. 2014a. Effect of pollination on rapeseed (Brassica campestris L. var. toria) production in Chitwan, Nepal. J Agric Environ 15: 41-45. DOI: 10.3126/aej.v15i0.19814.

Pudasaini R, Thapa RB. 2014b. Foraging behavior of different bee species under cage and open condition in Chitwan, Nepal. NY Sci J 7 (8): 94-97.

Pudasaini R. 2014. Abundance of flower visiting insects in rapeseed (Brassica campestris L. var. toria) field affected by the distance of natural habitat. Sky J Agric Res 3 (11): 223-227. 
Qin Q, He X-J, Tian L-Q, Zhang S-W, Zeng Z-J. 2012. Comparison of learning and memory of Apis cerana and Apis mellifera. J Comp Physiol 198 (10): 777-786. DOI: $10.1007 /$ s00359-012-0747-9.

Salamah A, Luthfikasari R, Dwiranti A. 2019. Pollen morphology of eight tribes of Asteraceae from Universitas Indonesia Campus, Depok, Indonesia. Biodiversitas 20 (1): 152-159. DOI: 10.13057/biodiv/d200118.

Sihag RC, Gupta M. 2011. Development of an artificial pollen substitute/supplement diet to help tide the colonies of honey bee (Apis mellifera L.) over the dearth season. J Apic Res 55 (2): 15-29.

Somerville D. 2005. Fat Bees Skinny Bees - A Manual on Honey Bee Nutrition for Beekepeers. Rural Industries Research and Development Corporation, New South Wales, Australia.

Sudarmono. 2019. Short Communication: Pollen diversity in the Bogor Botanic Gardens, Indonesia. Biodiversitas 20 (4): 931-936. DOI: $0.13057 /$ biodiv/d200401.

Sudarmono, Sahromi. 2012. Pollen atau serbuk sari: Aspek morfologi, sistematika dan aplikasinya pada tumbuhan keluarga mentol. J Sains Natural Universitas Nusa Bangsa 2 (1): 12-16. DOI: 10.31938/jsn.v2i1.30. [Indonesian]

Suwannapong G, Maksong S, Yemor T, Junsuri N, Benbow ME. 2013. Three species of native Thai honey bees exploit overlapping pollen resources:
Identification of bee flora from pollen loads and midguts from Apis cerana, A. dorsata and A. florea. J Api Res 52 (5): 196-201. DOI: 10.3896/IBRA.1.52.5.05

Tan K, Yang S, Wang Z-W, Radloff SE, Oldroyd BP. 2012. Differences in foraging and broodnest temperature in the honey bees Apis cerana and $A$. mellifera. Apidologie 43: 618-623. DOI: 10.1007/s13592-012-0136-y.

Tumminello G, Volk TA, Heavey JP. 2017. Shrub Willows Support a Wide Diversity of Bees. Factsheet. The Research Foundation for the State University of New-York, College of Environmental Science and Forestry, New York, US.

Widowati R, Basukriadi A, Oetari A, Anwar E, Sjamsuridzal W. 2013. The effect of pollen substitutes on the productivity of Apis cerana in Indonesia. Bee World 90 (3): 72-75. DOI: 10.1080/0005772X.2013.11417550.

Widowati R, Mariandayani HN, Rahayu IL, Sjamsuridzal W, Basukriadi A, Oetari A. 2020. Soybean dregs as main ingredients of pollen substitute for Apis cerana honey bees. Intl J Mod Agric 9 (4): 541-555.

Yolanda V, Sukarsa, Hidayah HA. 2020. Identification of pollen characteristics as Apis cerana feed sources in honeycomb, in Serang Purbalingga. BioEksakta 2 (1): 42-48. DOI: 10.20884/1.bioe.2020.2.1.1814. 